Uyar, S. (2019). Delaying Behavior in Institutions: Procrastination. Journal of Academic Perspective on Social Studies, (1), 40-43.

\title{
DELAYING BEHAVIOR IN INSTITUTIONS: PROCRASTINATION
}

\begin{abstract}
Human-resource, whose importance cannot be denied for institutions, can contribute to the institution with the knowledge and skills they have. On the other hand, they can punish the institution with different behaviors. Procrastination, interpreted as a coping mechanism (Burka and Yuen, 1983, p.60), is a complex fact that has behavioral, emotional, and cognitive features (Kovylin, 2013, p. 27).

In this study, the procrastination term was defined and the factors that cause the procrastination behavior were explained. In addition, the correlated dimensions and the results from the point of institutions were discussed.
\end{abstract}

Keywords: Procrastination, Delay, Workplace procrastination

\section{INTRODUCTION}

Procrastination is defined as delaying of a task that is under an individual's control where the delay itself is voluntarily and under the control of the individual (Wan et al., 2014, p. 87). It is also defined as a delay due to the prevention of the implementation of a purpose (Metin et al., 2016, p. 254). Procrastination behavior includes non-work-related actions that are not intended to harm the employer, employee, workplace or customer. (Metin et al., 2016, p. 254). Procrastination in the workplace is mainly due to the wide use of technology. Employees can give an impression of working on their computers, do shopping online, exhibit behaviors such as tending to social networking sites, playing games or instant messaging (Garrett and Danziger, 2008a; Garrett and Danziger, 2008b). Workplace procrastination can also be observed through long breaks, gossiping or daydreaming (Metin et al., 2016, p. 255).

According to the theory of time motivation, each person prioritizes the work/action/task that will benefit the most in a certain time frame. Factors such as the expectancy, value, delay, and sensitivity to delay are considered as important in procrastination, so the higher work-related expectations and the higher significance of the results will lower the rate of procrastination (Steel, 2007, p.72).

\section{What is Procrastination?}

Procrastination can be explained the notions of 'circumlocution' or 'postpone to tomorrow' beside the expression of 'habit of postponing' (Sadykova, 2016, p. 98). The word itself comes from the Latin word procrastinatus: pro (forward) and crastinus (of tomorrow) (Gafni and Geri, 2010, p. 115). Procrastination behavior is seen as a common phenomenon in the society and it is argued that every individual exhibits it (Wan et al., 2014, p. 87).

Procrastination is defined as continuous postponement of undesirable thoughts and work/ duties, the mechanism of coping with anxiety caused by start/end of work/tasks or decision-making processes, and the failure of self-regulation (Burka and Yuen, 1983, p. 60). It is a psychologically complex phenomenon that includes behavioral, emotional, and cognitive components related to the motivational field of the individual (Kovylin, 2013, p. 27). Procrastination behavior is not due to the difficulty of the working

\footnotetext{
${ }^{1}$ Ankara Hacı Bayram University, Faculty of Economics and Administrative Sciences, Healthcare Management Department, seda_inan@outlook.com, ORCID ID: https://orcid.org/0000-0001-8051-8464
} 
process during reaching the target, but because the target is perceived as inaccessible (Ferrari, 1992, p. 318). Procrastination is also indicated as a postponing of planned actions, urgent and important work/tasks continuously (Burka and Yuen, 1983, p. 65), and avoidance of doing an undesired work/task (Milgram and Tenne, 2000, p. 145-146). Procrastination behavior studies in the literature focus on procrastination behavior in academic and general life domains (Metin et al., 2016, p. 254). As seen in Table 1, procrastination behavior can be seen in all areas of life.

\section{Table 1. The Procrastination Behavior Grouping}

\begin{tabular}{|c|c|}
\hline \multicolumn{2}{|c|}{ The Procrastination Behavior Grouping of Milgram and Tenne (2000, p. 145-146) } \\
\hline $\begin{array}{l}\text { Academic } \\
\text { Procrastination }\end{array}$ & Delaying the academic assignments until the last minute. \\
\hline $\begin{array}{l}\text { Procrastination in Daily } \\
\text { Tasks and Life Duties }\end{array}$ & Difficulty in the scheduling of recurring life routines and doing them on schedule. \\
\hline Decisional Procrastination & Postponing of making timely decisions in minor matters. \\
\hline Compulsive Procrastination & Decisional and task procrastination in the same person. \\
\hline \multicolumn{2}{|c|}{ The Procrastination Behavior Grouping of Burka and Yuen $(1983$, p. 65) } \\
\hline $\begin{array}{l}\text { Nork } \\
\text { stination }\end{array}$ & $\begin{array}{l}\text { Postponement of daily work at home, such as cleaning the house, grocery } \\
\text { shopping, and repair work. }\end{array}$ \\
\hline ination & $\begin{array}{l}\text { Not to go to work on time, not attend the meetings on time, delaying the making } \\
\text { decision, postponing the writing a report. }\end{array}$ \\
\hline $\begin{array}{l}\text { Academic } \\
\text { Procrastination }\end{array}$ & $\begin{array}{l}\text { Postponement of the work to be done in the school, not to attend classes, not to do } \\
\text { homework on time, study for an exams at the last moment, delay writing of } \\
\text { homework, postpone bureaucratic procedures (such as payment of school fee), not } \\
\text { to give books on time to be returned to the library. }\end{array}$ \\
\hline $\begin{array}{l}\text { Procrastination in Personal } \\
\text { Care Related Works }\end{array}$ & $\begin{array}{l}\text { To postpone physical exercise, to lose weight, to stop smoking, to stop taking baths } \\
\text { or to buy new clothes, to quit health related problems. }\end{array}$ \\
\hline $\begin{array}{l}\text { Procrastination in Social } \\
\text { Relationships }\end{array}$ & $\begin{array}{l}\text { Postponing activities such as calling friends, visiting relatives, being together with } \\
\text { other people. }\end{array}$ \\
\hline $\begin{array}{l}\text { Procrastination in Works } \\
\text { Related to the Financial } \\
\text { Situation }\end{array}$ & $\begin{array}{l}\text { To postpone the payment of debts to corporations or persons, the payment of } \\
\text { invoices, to call the bank for a question about the banks, etc. }\end{array}$ \\
\hline \multicolumn{2}{|c|}{ The Procrastination Behavior Grouping of Milgram et al. (1995, p. 145) } \\
\hline $\begin{array}{l}\text { Daily } \\
\text { Procrastination }\end{array}$ & $\begin{array}{l}\text { Postpone works that should be carried out regularly (house cleaning, shopping, } \\
\text { etc.). }\end{array}$ \\
\hline Decisional Procrastination & Postponement of making decisions in general also including unimportant ones. \\
\hline $\begin{array}{l}\text { Neurotic } \\
\text { Procrastination }\end{array}$ & To postpone vital decisions (choice of profession, marriage, etc.). \\
\hline Compulsive Procrastination & Decisional and behavioral procrastination concurrently. \\
\hline $\begin{array}{l}\text { Academic } \\
\text { Procrastination }\end{array}$ & Postponement of homework, preparation of an exam/project. \\
\hline \multicolumn{2}{|r|}{ The Procrastination Behavior Grouping of Kovylin (2013, p. 27) } \\
\hline $\begin{array}{l}\text { Behavioral } \\
\text { Procrastination }\end{array}$ & Refers to the postponement of the expected activities/duties. \\
\hline Decisional Procrastination & $\begin{array}{l}\text { Explains the postponement of decision-making processes on whether to perform } \\
\text { certain activities/tasks. }\end{array}$ \\
\hline
\end{tabular}


Procrastination is seen as a reflection of the emotional responses to the tasks or tasks that need to be done (Platonov, 2004, p. 176). According to the nature of the reactions, there are two types of procrastination: 'comfortable' and 'nervous'. 'Comfortable' procrastination refers to tending to more pleasurable and entertaining interests for the individual rather than performing the works/tasks that an individual should do. 'Nervous' procrastination is associated with general intensity, loss of time, dissatisfaction with the quality of individual acquisitions, uncertainty of purposes, lack of courage and lack of self-confidence (Sadykova, 2016, p. 100-101).

Solomon and Rothblum (1984, p. 509) explain the reasons of procrastination habit with the concern of not being able to master the situation, perfectionism, difficulty in decision making, dependence on others and outside help. Ratsameemonthon (2015, p. 78) examine the procrastination as avoidance of certain tasks and fear of frustration, overconfidence/lack of self-confidence, laziness, fear of success, exhaustion and bad time management, revolt against control, risk-taking and peer effect.

\section{RESULT}

Procrastination, which is seen as a defense mechanism to counter the impact of workplace concerns such as occupational stress or distress (Wan et al., 2014, p. 87), is especially used in cases where there are conflicting alternatives (Ferrari, 1994, p. 677). Job characteristics, executive/leader characteristics, working conditions seem to be associated with procrastination (Wan et al., 2014, p. 87). Procrastination behavior is more common in cases, especially where the probability of failure is high (Ferrari, 1992, p. 316). Lack of incentive, difficult and imposed jobs force the individual for procrastination (Wan et al., 2014, p. 87). According to Metin et al. (2016, p. 254), job enrichment causes procrastination behavior in the current task because it makes difficult to make decisions. Procrastination behavior is observed when the employee is loaded with a charge other than his responsibility (Wan et al., 2014, p. 86). Lack of material motivators also causes procrastination behavior in employees (Metin et al., 2016, p. 254). Workplace procrastination, which is a socially acceptable label, results in underperformance in the individual (Ferrari, 1992, p. 316).

In the literature, it was seen that procrastination is related to the nature of the task (Blunt ve Pychyl, 2000 , p. 153), time management (Ferrari ve Díaz- Morales, 2007, p. 707), motivation (Çavuşoğlu and Karataş, 2015, p. 735; Rakes and Dunn, 2014, p. 799), self-esteem and self-efficacy (Ferrari, 1994, p.673; Kovylin, 2013, p. 27), performance (Ariely and Wertenbroch, 2002), stress (Milgram, Marshevsky and Sadeh, 1995, p. 145), role ambiguity and role conflict (Sadykova, 2016), personality (Milgram, Marshevsky and Sadeh, 1995, p. 145), and dimension perfectionism (Rakes and Dunn, 2014).

Procrastination is not only related to the workplace but also it is seen as a current problem in the academic framework. Academic procrastination behavior is mostly seen in the tasks expected from students such as preparing for exams, doing homework, and postponing the meeting (Kandemir and Palanc1, 2014, p. 195).

Procrastination behavior is not seen as an effective technique for life success (Ferrari, 1994, p.673). In addition, workplace procrastination is also associated with high costs (Metin et al., 2016, p. 254). Studies have also shown that the employees at higher status have more procrastination behavior (Ferrari, 1994, p.673; Wan et al., 2014, p. 87).

\section{REFERENCE}

Ariely, D. ve Wertenbroch, K. (2002). Procrastination, Deadlines, and Performance: Self-Control by Precommitment. Psychological Science, 13(3), 219-224.

Blunt, A. K. ve Pychyl, T. A. (2000). Task aversiveness and procrastination: A multi-dimensional approach to task aversiveness across stages of personal projects. Personality and Individual Differences, 28(1), 153-167.

Burka,J.B. ve Yuen, L.M. (1983). Procrastination: why you do 1t, what to do abaut 1t. New York Addison-Wessley. 
Çavuşoğlu, C. ve Karataş, H. (2015). Academic procrastination of undergraduates: Self-determination theory and academic motivation. Anthropologist, 20(3), 735-743.

Ferrari, J. R. ve Diaz-Morales, J. F. (2007). Procrastination: Different time orientations reflect different motives. Journal of Research in Personality, 41, 707-714.

Ferrari, J. R. (1992). Procrastination in the Workplace: Attributıons for Fa1lure Among Individuals With Similar Behavioral Tendencies. Person. individ. Diff., 13(3), 315-319.

Ferrari, J. R. (1994). Dysfunctional Procrastination and its Relationshıp With Self-Esteem, Interpersonal Dependency, and Self-Defeatıng Behaviors. Person. individ. Diff., 17(5), 673-679.

Gafni, R. ve Geri, N. (2010). Time management: Procrastination tendency in individual and collaborative tasks. Interdisciplinary Journal of Information, Knowledge, and Management, 5, 115-125.

Garrett, K. R., ve Danziger, J. N. (2008a). On cyberslacking:Workplace status and personal internet use at work. Cyberpsychology \& Behavior, 11, 287-292.

Garrett, K. R., ve Danziger, J. N. (2008b). Disaffection or expected outcomes: Understanding personal internet use during work. Journal of Computer-Mediated Communication, 13, 937-958.

Kandemir, M. ve Palanc1, M. (2014). Academic functional procrastination: Validity and reliability study. Procedia - Social and Behavioral Sciences 152, $194-198$.

Kovylin, V. S. (2013). Teoreticheskiye osnovy izucheniya fenomena prokrastinatsii. Lichnost' v Menyayushchemsya Mire: Zdorov'ye, Adaptatsiya, Razvitiye, 2, 22-41.

Metin, U. B., Taris, T. W., ve Peeters, M. C. V. (2016). Measuring procrastination at work and its associated workplace aspects, Personality and Individual Differences 101, 254-263.

Milgram, N. A., Marshevsky, S. ve Sadeh, C. (1995). Correlates of academic procrastination: Discomfort, task aversiveness and task capability. Journal of Psychology, 129(2), 145- 15

Milgram,N. ve Tenne, R. (2000). Personality correlates of decisional and task avoidant procrastination. European Journal of Personality 14: 141-156

Platonov, K. K. (2004). Kratkiy slovar' sistemy psihologicheskih ponyatiy. Moskva: Visshaya Shkola.

Rakes, G. C. ve Dunn, K. E. (2014). The influence of perfectionism on procrastination in online graduate education students. In M. Searson \& M. Ochoa (Eds.), Proceedings of society for information technology \& Teacher education international conference 2014 (pp. 799-803). Chesapeake, VA: Association for the Advancement of Computing in Education (AACE).

Sadykova, G. (2016). İş Güvencesizliği İle İşyeri Prokrastinasyonu (Erteleme Alışkanlığı) İlişkisi. Int. Journal of Management Economics and Business, 12(30) 97-120.,

Solomon, L. J. \& Rothblum, E. D. (1984). Academic procrastination: Frequency and cognitivebehavioral correlates. Journal of Counseling Psychology, 31(4), 503-509.

Steel, P. (2007). The nature of procrastination: A meta-analytic and theoretical review of quintessential self-regulatory failure. Psychological Bulletin, 133(1), 65-94.

Wan, H. C., Downey, L. A. ve Stough, C. (2014). Understanding Non-Work Presenteeism: Relationships Between Emotional İntelligence, Boredom, Procrastination and Job Stress. Personality and Individual Differences. 65, 86-90. http://dx.doi.org/10.1016/j.paid.2014.01.018. 